\title{
$\begin{array}{llllll}S & \mathrm{~T} & \mathrm{U} & \mathrm{D} & \mathrm{I} & \mathrm{A}\end{array}$
}

Irena Valikonytè

Uniwersytet Wileński

\section{Struktura i zasady kompletowania ksiąg sądowych Metryki Litewskiej Zygmunta Augusta}

\begin{abstract}
Zarys treści
W artykule omówiono strukturę i zasady kompletowania ksiąg sądowych Zygmunta Augusta w Metryce Litewskiej. Najwięcej uwagi poświęcono na analizę genezy i struktury tzw. ksiąg pisarza Jana Szymkowicza (35. księga spraw sądowych i 38. księga wpisów), do których wpisano dokumenty powstałe w ciągu 14 lat (1554-1568). W konkluzji stwierdzono, że w okresie panowania Zygmunta Augusta oraz pełnienia funkcji kanclerza przez Mikołaja Radziwiłła „Czarnego” w kancelarii Wielkiego Księstwa Litewskiego nie wypracowano jednego modelu kształtowania i kompletowania ksiąg sądowych władcy, chociaż w połowie XVI w. coraz częściej zajmowali się tym pisarze wielkiego księcia.
\end{abstract}

\begin{abstract}
This article explores the structure and patterns of formation of court registers included in the Lithuanian Metrica of King Sigismund Augustus. The text focuses on the development and composition of the books attributed to the scribe called Jan Szymkowicz (Court Record Book no. 35, Book of Entries no. 38), with documents spanning a fourteen-year period (1554-1568). The article concludes that during King Sigismund Augustus' rule, under the chancellorship of Mikołaj Radziwiłł called Czarny (The Black), there was in the chancery of the Grand Duchy of Lithuania no uniform pattern to be followed in order to make the king's court registers, despite the fact that, in the mid-sixteenth century, chancery's scribes usually influenced the chronological scope and structure of these registers.
\end{abstract}

Słowa kluczowe: Metryka Litewska, księgi spraw sądowych, proces sądowy, kancelaria Wielkiego Księstwa Litewskiego, dokument sądowy, Zygmunt August, Jan Szymkowicz, pisarze

Keywords: Lithuanian Metrica, court books, lawsuit, chancery of the Grand Duchy of Lithuania, judicial documents, Sigismund Augustus, Jan Szymkowicz, scribes

W badaniach nad Metryką Litewską od dawna rozpatrywana jest kwestia genezy i układu jej ksiąg według charakteru dokumentów, związana z problemem niezgodności ksiąg oryginalnych z księgami-kopiami. Badania struktury ksiąg, 
Irena Valikonytė

zainicjowane przez Nikołaja Bierieżkowa ${ }^{1}$ (a częściowo także przez Matwieja Lubawskiego i Iwana Łappo ${ }^{2}$ ), zostały wznowione przez Egidijusa Banionisa ${ }^{3}$. Ich szczególny rozkwit nastąpił zaś w końcu XX w., gdy na nowo podjęto publikację tomów Metryki Litewskiej, a swoje poglądy przedstawili wówczas: Krzysztof Pietkiewicz ${ }^{4}$, Aliaksandr Hrusza ${ }^{5}$, Artūras Dubonis ${ }^{6}$, Laimontas Karalius ${ }^{7}$, Darius Antanavičius ${ }^{8}$ i inni. Jednak dotychczasowe badania struktury ksiąg Metryki skupiały się przede wszystkim na analizie ksiąg wczesnych, do których wpisano dokumenty z okresu od końca XV do początku XVI w. Dotyczy to również kwestii poszukiwania modelu układu ksiąg spraw sądowych (KSS), czym zajął się Stanislovas Lazutka oraz Irena Valikonytè9

Oczywiście o zawartości każdej z ksiąg spraw sądowych decydowała przede wszystkim działalność konkretnego sądu - każdy prowadził księgi, w których umieszczano odpisy/wpisy dokumentujące jego działalność. Poniżej omawiam księgi sądowe władcy. Badając ich układ z pierwszej połowy XVI w., doszłam do wniosku, że w owym czasie nie występował jednolity i jedyny model kształtowania ksiąg sądowych, choć „prowadzone przez pisarzy zeszyty (rejestry, sprawy, minutariusze) były klasyfikowane lub profilowane". Jednak system archiwizacji dokumentów sądowych - jako że wpływ na specyfikę prowadzenia tych ksiąg miał ustrój sądów i procedura sądowa - nie mógł powstać od razu, a tym bardziej jednolity. $\mathrm{Z}$ tego wynikało, że „raczej możemy tu mówić o zorganizowanej i systematycznej różnorodności, na którą miał wpływ wzrost [...] kultury

${ }^{1}$ Н. Бережков, Литовская Метрика как исторический источник, t. 1: О первоначальном составе книг Литовской Метрики по 1522 год, Москва-Ленинград 1946.

2 М. Любавский, Литовско-Русский сейм, Москва 1900, s. 388; И.И. Лаппо, Великое княжество Литовское за время от заключения Люблинской унии до смерти Стефана Батория (1569-1586), С. Петербург 1901, s. 404.

3 Э. Банёнис, К вопросу о генезисе посольских книг (1480-1486), w: Исследования по Литовской Метрике, t. 1, Москва 1989, s. 64-84; idem, К вопросу о генезисе книг Литовской Метрики (последняя четверть XV в.), w: Lietuvos Metrika: 1988 metu tyrinejiimai, Vilnius 1992, s. 8-45.

${ }^{4}$ K. Pietkiewicz, Wielkie Księstwo Litewskie pod rządami Aleksandra Jagiellończyka. Studia nad dziejami państwa i społeczeństwa na przełomie XV i XVI wieku, Poznań 1995, s. 36-42.

5 А. Груша, Канцылярыя Вялікага княства Літоускага 40-х гадоў XV - першай паловь XVI cm., Мінск 2006, s. 92-115.

${ }^{6}$ A. Dubonis, D. Antanavičius, R. Ragauskienė, R. Šmigelskytè-Stukienė, Susigrąžinant praeitị. Lietuvos Metrikos istorija ir tyrimai, Vilnius 2016, s. 25-49.

7 L. Karalius, Lietuvos Metrikos knygu vaidmuo Aleksandro Jogailaičio kanceliarijoje (problemos aktualumas ir tyrimo perspektyvos), „Istorijos šaltinių tyrimai” 1, 2008, s. 175-217.

8 D. Antanavičius, Originalių Lietuvos Metrikos XVI a. knygų sąrašas, „Istorijos šaltinių tyrimai” 4, 2012, s. $157-184$.

9 S. Lazutka, I. Valikonytè, J. Sinkevičiūtè, İvadas, w: Lietuvos Metrika (1533-1535). 8-oji teismu bylu knyga, Vilnius 1999, s. XII-XIX; I. Valikonyte, W poszukiwaniu modelu układu najstarszych ksiag spraw sadowych Metryki Litewskiej, w: Lietuvos Didžiosios Kunigaikštystès istorijos šaltiniai: faktas, kontekstas, interpretacija, red. A. Dubonis, Vilnius 2010, s. 109-127. 
piśmiennictwa" oraz poziom biurokracji w ówczesnej Litwie ${ }^{10}$. W tej sytuacji interesujące jest pytanie, czy sytuacja w kancelarii Wielkiego Księstwa Litewskiego nie uległa zmianie w okresie panowania Zygmunta Augusta. Można by zakładać, że po półwieczu, kiedy wypróbowano różne modele funkcjonowania, logiczną konsekwencją byłby wybór jednej formy układu ksiąg spraw sądowych - najbardziej wygodny w archiwizacji dokumentów i dla użytkownika. Z innej strony pojawia się pytanie, kto mógł zadecydować o tym, który model lub modele są najdogodniejsze i najbardziej odpowiednie. Innymi słowy: czy można dostrzec związek pomiędzy procesami kształtowania się układu ksiąg sądowych Metryki i biurokratyzacji działalności kancelarii. Celem niniejszego artykułu jest próba znalezienia odpowiedzi na te pytania. Co prawda poszukiwanie modeli słuszniej byłoby powiązywać nie $\mathrm{z}$ objęciem tronu przez nowego władcę, ale raczej ze zmianą kanclerzy litewskich, w tym przypadku - z okresem działalności Mikołaja Radziwiłła „Czarnego". Trzeba więc położyć nacisk na okres sprawowania przez niego urzędu (1550-1565). Mówimy jednak o księgach sądowych hospodara, tym bardziej że - jak się zdaje - kanclerz nie miał większego wpływu na kształtowanie się ksiąg sądowych.

Podstawą takiej analizy są oczywiście księgi sądowe władcy - Zygmunta Augusta. Jak wiadomo, wielkim księciem litewskim został on w 1544 r., jeszcze za życia swego ojca, który przywilejem z 6 października 1544 r., przekazując uprawnienia władcy litewskiego synowi, wymienił także prawo wymierzania sprawiedliwości ${ }^{11}$, którą strony procesowe czasem określały nawet jako „столец судовый господарский"12. Okres pełnienia przez ostatniego Jagiellona funkcji wielkiego księcia nie był krótki, a zatem i ksiąg sądowych powstało sporo. Nie wiemy, ile ich było w ogóle, ale w Metryce Litewskiej możemy odnaleźć co najmniej jedenaście ksiąg odpisów dokumentów dotyczących wymierzanej przez samego władcę sprawiedliwości ${ }^{13}$. Oczywiście w krótkim artykule nie da się przeprowadzić gruntownej analizy wszystkich ksiąg. Dlatego poniżej zwrócę jedynie uwagę na najważniejsze cechy niektórych ksiąg, zwłaszcza dzielące je różnice.

Księgi sądowe musiały być, co oczywiste, tworzone w porządku chronologicznym. Odrębną kwestią jest sposób pojmowania tej zasady. Za panowania Zygmunta Augusta księgi spraw sądowych najczęściej sporządzano z dokumentów obejmujących okres 3-5 lat, chociaż zdarzały się wyjątki, gdy oddzielną księgę stanowily dokumenty pochodzące z jednego roku. Bodaj pierwszą księgą spraw sądowych Zygmunta Augusta, która - co prawda wolą archiwistów - trafiła do

${ }^{10}$ I. Valikonyte, op. cit., s. 111.

${ }^{11}$ L. Kolankowski, Zygmunt August wielki książę Litwy do roku 1548, Lwów 1913, s. 364-366.

12 Lietuvos Metrika (1540-1541). 10-oji teismu bylu knyga, wyd. S. Lazutka, I. Valikonytė, S. Viskantaitė-Saviščevienè, Vilnius 2003, nr 98, s. 70.

13 С. Пташицкий, Описание книг и актов Литовской Метрики, Санкт Петербург 1887, s. 85, $115-118$. 
serii ksiąg wpisów, jest tzw. 30. księga wpisów. Znalazły się w niej dokumenty z 1546 r. $^{14}$, a dokumenty z lat 1546-1547 trafiły do 29. księgi wpisów ${ }^{15}$. Do tzw. 24. KSS (obecnie ML 239) wpisano jedynie dokumenty z drugiej połowy $1551 \mathrm{r}^{16}$ Wydaje się, że najbardziej intensywnie władca pracował w szóstej i siódmej dekadzie stulecia, a przynajmniej do takiego stwierdzenia uprawniają zachowane, starannie od 1554 r. prowadzone księgi sądowe, których było aż pięć: 34. - za lata $1554-1556^{17}$, 37. - $1555-1558^{18}, 40$. - 1559-1563 ${ }^{19}, 47 .-1562-1566^{20}$ i $35 .-1554-$ $-1568^{21}$. Jednak z takiego stosunkowo konsekwentnego porządku chronologicznego wyłamuje się 35 . KSS, z racji swej ogromnej objętości oraz długiego okresu, który obejmuje - wpisano bowiem do niej dokumenty z lat 1554-1568. A zatem pamiętając, że z dokumentów pochodzących $\mathrm{z}$ tego samego okresu uformowano jeszcze cztery księgi sądu władcy (tzn. pokrywa się chronologia dokumentów, ale nie ich treść, za wyjątkiem kilku identycznych dokumentów spisanych do dwóch ksiąg), musimy zadać pytania: jakie były przyczyny założenia 35. KSS (obecnie ML 249) i co spowodowało nagromadzenie w jednej księdze dokumentów z tak długiego okresu? Hipoteza, że oryginalna księga o takiej objętości w ogóle nie istniała, nie daje się utrzymać, ponieważ została ona wpisana do sporządzonego 26 listopada 1623 r. rejestru oryginalnych ksiąg 22 .

Wydaje się, że inicjatorem założenia tej księgi był pisarz Jan Szymkowicz. Nie na próżno przecież wymieniono jego imię w tytule tej księgi, zarówno w rejestrze oryginalnych ksiąg (Metryka druga spraw sąowych pisarstwa tego p. Jana Szymkowicza od roku 1554 do roku 68) ${ }^{23}$, jak i w kopii księgi (Метрыка справ судовых, сознанья и оповеданья еtс. за панованья короля Жикгимонта Августа справ

14 Метрыка Вялікага Княства Літоўскага. Кніга 30 (1480-1546). Кніга записаў o 30, wyd. В.С. Мянжынскі, Мінск 2008 (dalej: ML 30).

15 Lietuvos Metrika. Knyga nr. 29 (1546-1547). Užrašymų knyga 29, wyd. I. Ilarienė, Vilnius 2016 (dalej: ML 29).

16 RGADA, f. 389, Литовская Метрика, ед. хр. 239 (dalej: ML 239).

17 Ibidem, ед. хр. 248 (dalej: ML 248).

${ }^{18}$ Lietuvos Metrika (1555-1558). 37-oji teismu bylų knyga, wyd. I. Valikonytė, L. Steponavičienè, Vilnius 2010 (dalej: ML 37).

19 Lietuvos Metrika (1559-1563). 40-oji teismu bylu knyga, wyd. N. Šlimienè, I. Valikonyte, Vilnius 2015.

${ }^{20}$ Lietuvos Metrika (1562-1566). 47-oji teismu bylu knyga, wyd. I. Valikonyte, N. Šlimiené, Vilnius 2011 (dalej: ML 47). Fakt, że z dokumentów z tego samego okresu skompletowano jeszcze jedną (50.) KSS można objaśnić następująco: wpisano do niej wyroki i protokoły spraw rozpatrywanych w dobie sejmu wileńskiego przez delegaturę sądu władcy - sąd marszałkowski; zob. Lietuvos Metrika (1565-1566). 50-oji teismu bylu knyga, wyd. L. Steponavičienė, I. Valikonytė, Vilnius 2014.

${ }^{21}$ Lietuvos Metrika (1554-1568). 35-oji teismu bylu knyga, wyd. S. Viskantaitė-Saviščevienė, I. Valikonyte, Vilnius 2018 (dalej: ML 35).

${ }^{22}$ D. Antanavičius, op. cit., s. 172, nr [53].

${ }^{23}$ Ibidem. 
пана Яна Шимковича от року 1554 до року 68) ${ }^{24}$. O „autorstwie” Jana Szymkowicza świadczy także zapis chorążyca miednickiego, diaka książęcego Piotra Stanisławowicza, znajdujący się na końcu tej księgi przy dwóch dokumentach (nr 299 i 307), a informujący o tym, że te dokumenty spisał on z rozkazu władcy i z polecenia Jana Szymkowicza ${ }^{25}$. Ponadto Szymkowicz samodzielnie decydował o wpisaniu do księgi niektórych dokumentów. Tak więc w zapisie z 21 czerwca 1556 r. wskazał, że Newidana Kliukowskaja prosiła o wpisanie nadania dworu dla swego mе̨ża „передо мъною” 26 , podobnie gdy razem z innymi wyznaczonymi przez władcę sędziami rozpatrywał sprawy w odpowiednich protokołach używał zaimka $я, \mathcal{м н е}^{27}$. Co prawda oryginalna księga pozostała bez tytułu (nie ma go przynajmniej w kopii), ale z pewnością stworzył ją autor rejestru oryginalnych ksiąg. Jej struktura charakteryzuje się bardzo konsekwentną chronologią dokumentów, ale nie ma żadnych „serii”, to znaczy w przeciwieństwie do najwcześniejszych ksiąg spraw sądowych nie kładzie się w niej nacisku ani na itinerarium władcy, ani na „sprawy” pisarza itp. To również świadczyłoby o tym, że księga ta stanowi zbiór dokumentów sporządzonych przez jednego pisarza.

Nie jest rzeczą nową, że jednym z modeli układu ksiąg spraw sądowych były księgi sporządzane „według (produkcji) pisarza”. Również w okresie panowania Zygmunta Augusta spisane przez jedną osobę poszyty dokumentów stawały się podstawą do tworzenia oddzielnej serii ksiąg czy całej księgi. Wyraźnie świadczą o tym wymienione wcześniej tytuły ksiąg oraz ich nazwy w rejestrach ksiąg oryginalnych oraz ksiąg-kopii. Na przykład 29. księgę ML rozpoczyna następujący wpis: „То сут книги справы декана и каноника виленьского, секретара и писара его кролевъскои милости князя Валеръяна" 28 . Owa rola Waleriana Protasowicza (sprawy) utrwalona jest także w nazwie księgi w obu rejestrach ${ }^{29}$. Jego imię wpisano również w tytule księgi-kopii ML 30, wskazując, że sprawy sądowe prowadzono „за писарства князя Валериянового”30. A zatem wystarczy spojrzeć na tytuły ksiąg wpisanych do rejestru oryginalnych ksiąg ML, w których oprócz chronologii dokumentów często wymieniano również imiona pisarzy (używając przy tym dwóch charakteryzujących ich pracę terminów: sprawy i pisarstwa), aby upewnić się, że w połowie XVI w. jednym z najważniejszych modeli układu ksiąg spraw sądowych (i nie tylko) była działalność konkretnego pisarza. Nie daje to

\footnotetext{
${ }^{24}$ ML 35, s. 1.

${ }^{25}$ Ibidem, s. 426, 445.

${ }^{26}$ Ibidem, nr 20, s. 52.

27 Ibidem, nr 11, 47, s. 47, 85.

28 ML 29, s. 21.

29 D. Antanavičius, op. cit., s. 171, nr [42]; Г. Голенченко, Реестр книг Метрики Великого княжества Литовского 1623 г. Исследования по истории Литовской Метрики, t. 2, Москва 1989, s. 344.

${ }^{30}$ ML 30, s. 56
} 
jednak odpowiedzi na pytanie, które z czynników zadecydowały o umieszczeniu w jednej księdze spraw sądowych odpisów dokumentów z tak dużego przedziału chronologicznego, tzn. sporządzonych przez Jana Szymkowicza w ciągu 14 lat? I dlaczego $\mathrm{z}$ tak wyjątkową sytuacją mamy do czynienia w przypadku właśnie jego?

Przyjrzyjmy się jego biografii. Bodaj pierwszy odnotował go Wojciech Kojałowicz-Wijuk w swoim herbarzu (Nomenclator) ${ }^{31}$, wskazując także jego herb - Kościesza. Ojciec Jana, syn dworzanina królewskiego Andrieja Mackowicza, Szymko Mackowicz był ciwunem i horodniczym wileńskim, a matka - druga żona Szymki - Zofia Pawłowna po owdowieniu poślubiła kniazia Wasyla Andrejewicza Połubińskiego. Karierę Jan rozpoczął najprawdopodobniej w 1540 r. jako dworzanin Zygmunta Starego, a później służył w kancelarii królowej Bony, w 1547 r. odnotowany jest jako pisarz królowej ${ }^{32}$. W 1551 r. został marszałkiem hospodarskim (urząd ten pełnił do śmierci), a 9 stycznia 1554 r. - pisarzem hospodarskim ${ }^{33}$. Jeszcze w końcu tego roku zaczął sporządzać dokumenty (pierwszy w księdze jest datowany 16 grudnia) sądu władcy, które następnie złożyły się na 35 . KSS ${ }^{34}$. 7 stycznia 1555 r. objął urząd, zastępując zmarłego w 1553 r. Stanisława Komorowskiego ${ }^{35}$. Nie wiadomo, w którym roku poślubił potomkinię znanego rodu Wiśniowieckich: Aleksandrę Iwanowną, ale w 1555 r. był już żonaty ${ }^{36}$. Z pewnością przez 15 lat nie stracił zaufania władcy, otrzymał dzierżawy: koniawską, dubicką, wiłkomierską oraz starostwo tykocińskie ${ }^{37}$. Był jednym z tych, których, mówiąc słowami biografa Stanisława Cynarskiego, Zygmunt August „trzymał przy sobie”. Zdaniem Cynarskiego „szczęśliwszą rękę miał Zygmunt August w doborze ludzi, którzy byli zatrudnieni w kancelarii królewskiej i w służbie dyplomatycznej"38. To spostrzeżenie można chyba odnieść także do urzędników wielkoksiążęcych. W każdym razie przynajmniej Szymkowiczowi władca powierzał również obowiązki w poselstwach litewskich do Moskwy. Jego kariera jako dyplomaty rozpoczęła się ewidentnie w 1555 r., gdy został pisarzem wielkim litewskim. Źródła wymieniają jego imię jako posła wielkiego w poselstwach do Moskwy 25 listopada 1555, 7 lutego 1556 i 4 grudnia 1560 r. Przewodził również wielkiemu poselstwu,

\footnotetext{
${ }^{31}$ A. Kojalavičius-Vijūkas, Šventasis Lietuvos Didžiosios Kunigaikštijos bei jai priklausančiu provinciju giminiu ir herbu vardynas, wyd. i tłum. S. Narbutas, Vilnius 2015, s. 626, 627.

32 ML 29, nr 142, s. 149.

33 Szczegółową biografię zob.: H. Lulewicz, Szymkowicz (Symkowicz) Jan, w: PSB, t. 50, Warszawa-Kraków 2015, s. 262-265; Urzędnicy centralni i dostojnicy Wielkiego Księstwa Litewskiego XIV-XVIII wieku. Spisy, oprac. H. Lulewicz, A. Rachuba, Kórnik 1994, s. 91, 244.

${ }_{34}$ ML 35, nr 1, s. 41.

35 A. Dubonis, D. Antanavičius, R. Ragauskienè, R. Šmigelskytè-Stukienė, op. cit., s. 87.

${ }^{36}$ ML 248, k. 131-134v.

37 H. Lulewicz, op. cit., s. 264.

38 S. Cynarski, Zygmunt August, Wrocław 1988, s. 72.
} 
które przybyło do Moskwy 6 lutego 1561 r. ${ }^{39}$ Oczywiście w czasie takich podróży jego działalność w charakterze pisarza sądowego ustawała ${ }^{40}$.

Nie powodowało to jednak problemów, ponieważ w Wielkim Księstwie - inaczej niż w Koronie, gdzie już w pierwszej połowie XVI w. działała odrębna kancelaria dekretów, obsługująca sąd asesorski ${ }^{41}$ - nie istniała nie tylko osobna kancelaria, ale nawet wyspecjalizowany urząd - pisarz sądowy. Sprawy protokołowali różni pisarze, którzy akurat znajdowali się przy władcy i nie wykonywali innych jego poleceń czy zadań. Na przykład Stanisław Komorowski rozpoczynając 24. KSS, zapisał, że Zygmunt August zlecił mu „записывати справы судовые и иные всякие [sic! - I.V.] которые бы ся кольвекъ перед его королевскую милость прыточыти мели"42. Tym można wyjaśnić fakt, że niektóre z ksiąg sądowych mają "nakładającą się" chronologię, a dokumenty sporządzone w tym samym roku trafiały do różnych ksiąg sądowych. Chociaż oczywiście można dostrzec pewną specjalizację - wynikającą z doświadczeń zdobytych w dłuższej perspektywie. Na przykład Jan Szymkowicz był niejednokrotnie delegowany przez władcę do składu sędziowskiego ustanawianego do rozpatrzenia konkretnej sprawy ${ }^{43}$.

Kolejnym, od dawna badanym zagadnieniem jest droga, jaką odbywał dokument od momentu wydania polecenia jego sporządzenia do chwili, gdy trafiał do księgi wieczystego przechowywania ${ }^{44}$. Przeanalizujemy jedynie dokumenty procesu sądowego (protokoły i wyroki). Jest oczywiste, że pisarz protokołując przebieg posiedzenia sądu, najpierw zaznaczał najważniejsze informacje $\mathrm{w}$ brudnopisie (minucie), a zbiór takich minut (wiązki lub poszyty) nazywano minutariuszami ${ }^{45}$.

39 E. Banionis, Lietuvos Didžiosios Kunigaikštystès pasiuntinybiu tarnyba XV-XVI amžiais, Vilnius 1998, s. 222-223; Lietuvos Didžiosios Kunigaikštystés ir Maskvos valstybès sutartys 1449-1556 metai, wyd. M. Sirutavičius, Vilnius 2016, s. 264, 274; H. Lulewicz, op. cit., s. 262-263.

${ }^{40}$ I rzeczywiście, ostatni dokument wpisany do 35. KSS jest datowany 21 XI 1555 r., a wpisy zostają wznowione w końcu maja 1556 r.; wpisy w 1560 r. urywają się 19 listopada, a wznowione są dopiero 31 V 1561 r.; ML 35, s. 50-51, 128-130. Między innymi decyzja Zygmunta Augusta z 18 XI 1555 r. o przełożeniu rozprawy pomiędzy Janem Szymkowiczem i Iwanem Liadskim jest umotywowana wysłaniem pisarza „у поселстве до Великого князства Московского”; ML 248, k. 143v.

${ }^{41}$ J. Szymański, Nauki pomocnicze historii, wyd. 5, nowe, przejrz. i zm., Warszawa 2002, s. 464.

${ }_{42}$ ML 239, k. 1.

${ }^{43}$ ML 35, nr 11, s. 47; ibidem, nr 47, s. 85; ML 37, nr 22, s. 43; ibidem, nr 102, s. 128.

${ }^{44}$ E. Banionis, Lietuvos Metrikos knygos: sąvoka, terminas, definicija, „Lietuvos istorijos metraštis 1988 metai” 1989, s. 135-148; K. Pietkiewicz, Księga 9 wpisów (заnuceŭ) Metryki Litewskiej, układ i zawartość, oraz jej kontynuacja do roku 1518 z Archiwum Radziwiłłowskiego, w: Lietuvos Metrika. 1991-1996 metu tyrinèjimai, Vilnius 1998, s. 11-35; J. Kiaupiené, XVI a. ikireforminio Vilniaus pilies teismo knygos-kopijos Lietuvos Metrikoje struktūrine ir informacine analizè, w: ibidem, s. 36-68; А. Груша, op. cit., s. 92-115.

45 „[...] помылно и в минутарах”, Lietuvos Metrika. Knyga nr. 47 (1565-1567). Užrašymų knyga 47, wyd. E. Deveikyte, G. Lesmaitis, Vilnius 2018, s. 27; „Minutarzów różnych spraw”, D. Antanavičius, op. cit., s. 175; „[...] rozkazawszy minutarze spisać”, Listy króla Zygmunta Augusta do Radziwiłłów, oprac., wstęp i koment. I. Kaniewska, Kraków 1999, s. 526. 
Już po zakończeniu procesu, który czasem przeciągał się do kilku dni lub znacznie dłużej, nagromadzone odpisy oryginalnych dokumentów czekały na swoją kolej wpisania do księgi. O tym, że dokumenty przepisywano do nich jeżeli nie z poszytu, to przynajmniej ze specjalnie ułożonej w porządku chronologicznym wiązki odpisów dokumentów świadczą uwagi, np. odsyłacze do dokumentu, który jakoby wpisany został нижей do tej samej księgi. W 1554 r. np. do 34. KSS wpisano wiele oświadczeń różnych osób o niezwróceniu im przez zmarłego podczaszego Stanisława Kieżgajły długów. W końcu pierwszego takiego dokumentu umieszczono uwagę: „и иншые, яко нижей естъ описано, приповедали ся передъ его кролевскою милостью" 46 . Należy również zauważyć, że wyroki wpisywano do ksiąg spraw sądowych konsekwentnie w porządku chronologicznym nie według daty ich wydania (tzn. zakończenia sprawy), ale na podstawie daty rozpoczęcia sprawy, ukazanej w eschatokole dokumentu. A zatem wydany stronie procesowej dokument sądowy nie był od razu wpisywany do księgi Metryki, jak to czyniono w przypadku nadania czy transakcji ${ }^{47}$.

Jednak tezę, że pisarze osobiście decydowali o wpisaniu sporządzanych przez siebie dokumentów najlepiej potwierdza zachowana w Metryce Litewskiej jedna księga utworzona na podstawie dokumentów obejmujących ten sam, długi okres 14 lat (1554-1568), tzw. 38. księga wpisów. W rejestrze oryginalnych ksiąg Metryki jest ona nazwana pierwszą księgą Jana Szymkowicza, a 35. KSS - drugą księgą Szymkowicza ${ }^{48}$. Po zapoznaniu się de visu z 38. księgą ML ${ }^{49}$ można stwierdzić, że dokumentów stricte sądowych jest $\mathrm{w}$ niej zaledwie cztery. A ich wciągnięcie do księgi wpisów jest pod pewnym względem uzasadnione. Na przykład list władcy podpisany 20 października 1557 r., „всимъ посполите и кождому зособна”, informujący o tym, że Ludmiła Borejkówna, która skarżyła Maśkę Szpakowskiego o zabójstwo jej męża, wycofała skargę, a więc nie może ona szkodzić czci Szpakowskiego i jego potomków. A zatem w księdze wpisów odnotowano nie wyrok sądowy, lecz jego prawomocne konsekwencje ${ }^{50}$. Z kolei dokument datowany 21 listopadem 1557 r. jest rzeczywiście wyrokiem sądu, którego wpisanie uzasadniano nawet nakazem władcy: „до книг судовых записати”. Ale wszystko

${ }^{46}$ ML 248, k. 58v.

47 A. Dubonis, D. Antanavičius, R. Ragauskienè, R. Šmigelskytė-Stukienė, op. cit., s. 40. Możliwe, że m.in. właśnie z dokumentów spisanych przez Jana Szymkowicza w oddzielnym poszycie-rejestrze ukształtowano także tzw. 42. księgę wpisów. Choć ani w tytule, ani w rejestrach ksiąg Metryki pisarza nie wskazano (D. Antanavičius, op. cit., nr [78], s. 174; Г. Голенченко, op. cit., nr [31], s. 347), jednak ze 104 dokumentów, które znalazły się w tej księdze (a przeważają wśród nich nadania włók), aż 41 (z lat 1557, 1559, 1560-1562) zostało podpisanych przez Jana Szymkowicza (Метрыка Вялікага Княства Літоўскага. Кніга 42 (1556-1562). Кніга записаў № 42, wyd. В.С. Мянжынскі, Мінск 2015).

48 D. Antanavičius, op. cit., s. 172, nr [52], [53].

49 RGADA, f. 389, Литовская Метрика, ед. хр. 38 (dalej: ML 38).

${ }^{50}$ Ibidem, ед. хр. 64, k. 82v-84v. 
wyjaśnia zdanie umieszczone pod wpisem: że wypis „справы пана Остафъя Воловича, писара, уписан тутъ для памети и ведомости, с чого прывилей господарский, нижей выписаный, справы пана Яна Шимковича, Роману Невельскому уросъ " ${ }^{\prime 1}$. I rzeczywiście następny umieszczony w tej księdze dokument (nr 73) jest przywilejem władcy na ziemię Teptiukowszczyznę, wydanym dla Romana Newelskiego ${ }^{52}$. Prawdopodobnie wynika to z faktu, że Jan Szymkowicz (wspólnie z Eustachym Wołłowiczem i Janem Hajką) zostali przez władcę delegowani do rozsądzenia sprawy ziemian mścisławskich. Do tej księgi wpisano również podpisany przez Szymkowicza list Zygmunta Augusta do starosty mścisławskiego Jana Sołomereckiego, informujący o podjętej przez władcę decyzji ${ }^{53}$. Być może jedynie wyrok ${ }^{54}$ przyjęty przez skład sędziowsko-marszałkowski, utworzony na mocy polecenia władcy z 26 maja 1556 r., w którym znajdował się również Jan Szymkowicz, musiał zostać wpisany do księgi sądowej, jest to bowiem jedyny dokument odbiegający od charakteru 38. księgi.

Co pokazuje porównanie chronologii dokumentów dwóch powstających w tym samym czasie ksiąg Jana Szymkowicza: pierwszej tj. 38. księgi wpisów oraz drugiej - 35. KSS? Nie ulega wątpliwości, że pisarz ten zaczął sporządzać dokumenty w Wilnie równocześnie - w grudniu $1554 \mathrm{r}$. (pierwszy dokument w pierwszej księdze jest datowany 19 grudnia, a w drugiej - 16 grudnia). Daty ostatnich wpisów w obu księgach również się pokrywają: w pierwszej księdze - 15 lipca 1568 r. w Grodnie (nr 417), a w drugiej - 4 sierpnia tegoż roku w Knyszynie (nr 334). Należy jednak zauważyć, że aż sześć poprzedzających go dokumentów (nr 328-333), wpisanych do drugiej księgi, sporządzono w Grodnie, przy czym pięć $\mathrm{z}$ nich tego samego dnia - 15 lipca, jeden zaś 16 lipca. A zatem dokumenty umieszczone w obu księgach gromadzono w tym samym czasie, co świadczyłoby o tym, że Jan Szymkowicz sporządzając w ciągu tych 14 lat różnorodne dokumenty, segregował je, zapewne przepisując czystopisy do oddzielnych, wyspecjalizowanych poszytów. Potwierdzają to wyraźnie dokumenty spisane przez niego tego samego dnia, a znajdujące się w różnych księgach (np. 7 I 1555, 16 III, 10 i 14 V oraz 26 VIII 1558, 15 VII 1568 r. itd.).

Powróćmy jednak do kwestii tak długiego okresu, którego dotyczą księgi spisane przez Jana Szymkowicza. Czy rzeczywiście zostały one wytworzone przez samego pisarza? Jeśli tak, to dlaczego tak długo zwlekał z ich utworzeniem? Przecież można było utworzyć kilka ksiąg z dokumentów obejmujących krótszy okres. Niewątpliwie pełniąc urząd pisarza przez dłuższy czas, zapełnił dokumentami niejeden poszyt. $Z$ pewnością na decyzje te wpływało przekonanie konkretnego pisarza, który poszyt i kiedy uznać za ukończony, aby móc rozpocząć nowy.

51 Ibidem, ед. хр. 72, k. 96.

52 Ibidem, ед. хр. 73, k. 98-99v.

53 Ibidem, ед. хр. 181, k. 260-261v.

54 Ibidem, ед. хр. 33, k. 42v-45v. 
Wspomniany już Stanisław Komorowski pracę w sądzie władcy i poszyt dokumentów sądowych (który zapoczątkował 24. KSS) rozpoczął 6 lipca 1551 r. ${ }^{55}$, a zakończył - można przypuszczać - dokumentem spisanym 6 września $1551 \mathrm{r}$. w Wigrach, a następny poszyt rozpoczął miesiąc później, 5 października ${ }^{56}$. Stał się on prawdopodobnie początkiem nowej serii. Pisarz wskazał następujący motyw: tego dnia sam władca „судил и справовалъ [...] на рокох судовых о светомъ Михале свята рымъского у Вильни". Po wymienieniu członków Rady Panów, którzy sądzili wspólnie $\mathrm{z}$ władcą, Komorowski ${ }^{57}$ zapisal jeszcze, że jednocześnie Zygmunt August raczył mu dać „писарство свое дворное и земъское [...], которое отъ его королевъское милости заведалъ и справовалъ теперешний бискупъ луцъкий князь Валерыянъ” i nakazał wszystkie sprawy sądowe spisywać „в сие книги его милости господарьские судовые”58. Oczywiste jest zatem, że pisarz postanowił zaznaczyć w księgach początek sesji sądowej wielkiego księcia, a także sprawowania przez siebie urzędu pisarza. A zakończył księgę wpis z 30 grudnia. $Z$ tego wynika, że rozpoczęcie i zakończenie księgi sądowej władcy zależało niekiedy od trwania sesji sądowej ${ }^{59}$, czasem - od momentu rozpoczęcia pracy pisarza w sądzie, czasem zaś od indywidualnego doświadczenia pisarza. Niewątpliwie w połowie XVI w. wpływ na model układu ksiąg sądowych władcy miała dążność do zachowania możliwie konsekwentnej chronologii wpisywanych dokumentów, co miało ułatwiać i usprawniać poszukiwania potrzebnej dokumentacji ${ }^{60}$. A taką ciągłość mogły zapewnić dokumenty sporządzanie przez tego samego pisarza, utrwalające działalność sądu władcy w pewnym okresie, albo księgi przeznaczone do wieczystego przechowywania, tworzone przez odpowiednią osobę z poszytów spisywanych przez siebie lub innych pisarzy.

Ostatnio w historiografii popularność zyskała ogłoszona jeszcze przez Nikołaja Bierieżkowa teza, że niektóre oryginalne księgi utworzono, przepisując dokumenty do przygotowanych zawczasu i oprawionych, czystych ksiąg61. Takie domniemanie może być obecnie potwierdzone dzięki tytułom i opisom niektórych ksiąg, które znajdują się w rejestrze oryginalnych ksiąg, np.: [nr 140, 141] „Księgi sądowe

${ }^{55}$ ML 239, k. 1.

56 Ibidem, k. 31.

57 Biografię Komorowskiego zob. R. Ragauskienè, Lietuvos Didžiosios Kunigaikštystès kancleris Mikalojus Radvila Rudasis (apie 1515-1584), Vilnius 2002, s. 310-311.

58 ML 239, k. 31v.

59 Zagadnienie sesji sądu hospodarskiego wymaga jeszcze zbadania.

${ }^{60}$ Zdaje się, że przypadki naruszania porządku chronologicznego w połowie XVI w. były już wyjątkiem. Osoba, która opracowała rejestr ruski 37. KSS, w kopii zwróciła uwagę na to, że 9 dokumentów sporządzonych w okresie od stycznia do sierpnia 1556 r. (nr 16-24) zostało w księdze umieszczonych za odpisami dokumentów utworzonych we wrześniu tegoż roku: „Тут даты непорадне месецов и дней писано"; ML 37, s. 4.

${ }^{61}$ D. Antanavičius, op. cit., s. 165; A. Dubonis, D. Antanavičius, R. Ragauskienè, R. Šmigelskytè-Stukienè, op. cit., s. 44. 
i inszych spraw [...]. Ta księga jest zupełna, a przy tej druga księga, zaczęto też sprawy pisać, ale nieskończona i ledwo trzecia część jest pisana"62. Być może pozwoli to wyjaśnić odmienną formę rozpoczynania różnych ksiąg sądowych. Niektóre z nich na początku zawierają wstęp opisujący itinerarium Zygmunta Augusta oraz określone przezeń obowiązki pisarza. Charakterystyczna jest więc przedmowa 24. KSS: „Панъ нашъ милостивый, прыехавшы с паньства своего, Коруны Польское, до другого паньства своего Великого князства Литовъского, до места столечного, до Вильни, на погребъ тела королевое, ее милости, и великое кнегини Барбары Радивиловъны, пани малъжонъки своее милое, рачылъ естъ [...] росказати и поручыти мне, Станиславу Якубовичу Коморовъскому с Конъдратишокъ, секретару своему [...] записывати справы судовые"63. Inne księgi otwiera natomiast jedynie formuła „Книги судовые господарские” lub „Книги судовые господара короля, его милости, и великого князя Жикгимонта Авъгуста канцлярейские"64. Jeszcze inne nie zostały w ogóle opatrzone ani wstępem, ani tytułem, po prostu na początku wpisano konkretny dokument (np. 34., 35. i 40. KSS), nie umieszczając nawet jego tytułu. Powstaje wrażenie, że pisarz zapisawszy jedną księgę, brał kolejną, czystą, oprawioną i kontynuował umieszczanie w niej wpisów.

Tak właśnie wygląda 35. KSS. Możliwe, że obie księgi Jana Szymkowicza zostały utworzone z zapisanych przez niego poszytów już po jego śmierci przez inną osobę. Co pozwala postawić taką hipotezę? Przede wszystkim „autorstwo” Szymkowicza zostało udowodnione, jak już wspomniano, jedynie w rejestrze oryginalnych ksiąg, wzmianek na ten temat nie ma już jednak w rejestrze ksiąg-kopii. Po drugie: trudno przyjąć, że do sporządzenia ksiąg, o tak ogromnej wszak objętości, Szymkowicz wykorzystał zawczasu oprawione woluminy (dokumenty zawarte w 35. KSS wpisano na ponad 570 kart, a 38. księgi wpisów - ponad 640 kart). Po trzecie: wspomniano już, że datą ostatniego wpisu w 35. KSS jest 4 sierpnia 1568 r., a wiadomo, że już w 1567 r. Szymkowicz chorował (męczyła go podagra i artretyzm) ${ }^{65}$, a na początku $1569 \mathrm{r}$. (po 8 marca, a przed 1 maja) zmarr ${ }^{66}$. A zatem możliwe, iż zapełnione przez niego poszyty mogły pozostać $\mathrm{w}$ jego domu, który nabył w Wilnie, niedaleko Ostrej Bramy ${ }^{67}$. Wiadomo bowiem, że kanclerze

${ }^{62}$ Cyt. za: D. Antanavičius, op. cit., s. 180.

${ }^{63}$ ML 239, k. 1.

${ }^{64}$ ML 37, s. 21; ML 47, s. 21.

65 R. Ragauskiené, Lietuvos Didžiosios Kunigaikštystès kancleris Mikalojus Radvila Rudasis..., s. 107, przyp. 123; idem, Mirties nugalèti nepavyko. Biržu ir Dubingiu kunigaikščiu Radvilu biologine istorija (XV a. pabaiga - XVII a.), Vilnius 2017, s. 235.

${ }^{66}$ H. Lulewicz, op. cit., s. 264.

67 Namiestnik wileński Stanisław Hamszej prosząc 2 VI 1567 r. o zwolnienie jego domu od „стоянья гостей”, zlokalizował go w ten sposób: „идучи з рынку ку Острой Браме по левой руце, подле дому маршалка и писара нашого, старосты тыкотынского, державцы вилкомирского, пана Яна Шимковича"; Lietuvos Metrika. Knyga nr. 51 (1566-1574). Užrašymų knyga 51, wyd. A. Baliulis, R. Ragauskiené, A. Ragauskas, Vilnius 2000, nr 67, s. 78. 
Wielkiego Księstwa Litewskiego traktowali księgi Metryki jak swoją własność, zabierając je i przechowując u siebie $\mathrm{w}$ domu ${ }^{68}$. Być może dlatego tolerowali oni praktyki niektórych, przynajmniej tych najbardziej wpływowych, pisarzy, którzy wzorując się na nich, odpisy dokumentów gromadzili w swych domach, nie spiesząc się z ich umieszczeniem w księgach Metryki, nie kontrolowali też swoich pomocników itd. Świadczy o tym list Zygmunta Augusta z 30 stycznia 1570 r. do Mikołaja Radziwiłła „Rudego”, w którym władca, zdziwiony, że Radziwiłł nie może nigdzie znaleźć „dokonczania [s] carza perekopskiego”, przypuszczał, że umowa mogła znajdować u "synowców” Radziwiłła, gdyż wojewoda wileński, sprawujący również urząd kanclerza, takie dokumenty przechowywał u siebie. Ale jednocześnie władca wyraził nadzieję („spodziewamy się”), że pismo może znajdować się „między listy kancelaryskimi sprawy nieboszczyka Szymkowicza [sic! - I.V.], które już są w ręku syna T[wojej] M[iłości] pana Mikołaja, za pojęciem małżonki Szymkowiczowej”"69. Władca zwraca uwagę Radziwiłła, że „wiela ksiąg, regestrów i przywilejów potrzebnych nieboszczyk Szymkowicz, które na ręku swych miał, a zwłaszcza na imiona gasztołtowskie, ktore sam popisował od nas, nam nie zdał i przy sobie je zachował, coś sobie abo komu inemu w tym za pożytek przywłaszczając, o czymeśmy mu wiadomością samego T[wojej] $\mathrm{M}$ [iłości] nie po jeden raz serio mówili i napominali go, aby je nam powracał. Tego nie uczynił”70. Dlatego zobowiązał „Rudego”, by „wywiedzenie skuteczne uczyniwszy", dokumenty odnalazł i monarsze odwiózł. Jest też możliwe, że z wymienionych w liście Zygmunta Augusta spisów dworów Gasztołda utworzono następnie wymienione w rejestrach ksiąg Metryki Litewskiej „rejestry” i „księgi”. Jako przykład można podać wpisany do rejestru oryginalnych ksiąg „Regestr zamku radoszkowskiego, z [?] czym na króla jego mości po Gasztołdzie spadł, opisany przez p. Jana Szymkowicza w roku 1549"71. Warto przytoczyć spostrzeżenie autora rejestru umieszczone na końcu wpisu: „Sprawy zaś na dobra Goształtowskie i insze spatkowe, do stołu króla jego mości należące, iż pewnego regestru i porządku nie miały, przystąpić do odbirania ich, ażby porządnie złożone byli, nie mogli"72. Wygląda więc na to, że Szymkowicz już w okresie służby dla Bony nie odznaczał się skrupulatnością i obowiązkowością, odkładając bądź nie nadążając z uporządkowaniem sporządzonych przez siebie odpisów oryginałów. Jak wiadomo, należyte zabezpieczenie dokumentów było jednym z najbardziej palących problemów całej kancelarii litewskiej. A nawyk wynoszenia dokumentów

68 R. Ragauskienè, XVI a. Lietuvos Didžiosios Kunigaikštystès kancleriai ir Lietuvos Metrika: valstybès kanceliarijos dokumentu saugojimo ypatybès, „Lietuvos Metrikos naujienos” 2003, nr 7, s. 30-40.

${ }^{69}$ Aleksandry Wiśniowieckiej, która po śmierci Szymkowicza w lutym 1570 r. poślubiła najstarszego syna Mikołaja Radziwiłła „Rudego”.

${ }^{70}$ Listy króla Zygmunta Augusta do Radziwiłłów..., s. 574.

${ }_{71}$ D. Antanavičius, op. cit., nr [77], s. 174.

72 Ibidem, s. 180. 
(tym bardziej ich odpisów) i przetrzymywania ich u siebie $\mathrm{w}$ domu nie był obcy i Szymkowiczowi.

Badacze zajmujący się kancelarią hospodarską podkreślają ogromną rolę kanclerza w organizowaniu jej pracy, szczególnie w połowie XVI w. Wydaje się jednak, że wprowadzane wówczas zmiany w funkcjonowaniu urzędu kanclerza w najmniejszym stopniu dotyczyły kształtowania i kompletowania ksiąg spraw sądowych, to bowiem były prerogatywy tzw. pisarzy wielkich. Można to wyjaśnić specyfiką działalności sądu. Z drugiej strony kanclerzy najbardziej interesowała ochrona dokumentów publicznych i związanych z przywilejami szlachty. Nie bez powodu zaznaczył to Mikołaj Radziwiłł "Czarny” w preambule nie tyle do ksiąg sądowych, ale do księgi wpisów, że do tej (35.) księgi wpisów wciągnięto dokumenty, które „свободы и вольности ширей объмовляють и годности водле заслугъ кождого стану ясне показуеть" "73.

Inną kwestią jest to, że na zawartość ksiąg sądowych władcy wpływ miał również sposób organizacji codziennej działalności tego sądu jako urzędu („kancelarii”). Porównanie dat dokumentów wpisanych do ksiąg sądowych hospodara pozwala zauważyć, że spisane tego samego dnia dokumenty trafiały do różnych ksiąg. Na przykład wyrok w sprawie rozpatrywanej przez władcę 16 kwietnia 1558 r. wpisano do 35 . KSS, a manifest strony procesowej - do 37 . KSS ${ }^{74}$, wyrok ze sprawy rozpatrywanej przez władcę 3 maja $1558 \mathrm{r}$. zapisano w 37. KSS, a oświadczenie pełnomocnika strony - w 35 . KSS ${ }^{75}$, itd. Można zatem domniemywać, że różne oświadczenia przekładane przez strony procesowe lub reprezentujących ich „prokuratorów” w poszytach rejestrowali zasiadający w kancelarii pisarze czy diacy. Świadczą o tym takie m.in. wpisy: „постановивши ся очевисте у канцлереи господара короля [...], до книг короля” lub „прышедшы до книгъ его кролевъское милости" ${ }^{\prime 6}$ itp. Można jednak przypuszczać, że nagromadzone w połowie XVI w. w sądzie władcy takiego rodzaju wpisy, później, podczas tworzenia ksiąg spraw sądowych przeznaczonych do wieczystego przechowywania, były umieszczane pomiędzy dokumentami rozpatrywanych spraw w porządku chronologicznym, a więc $\mathrm{z}$ takich zawierających wpisy-oświadczenia poszytów nie tworzono odrębnych ksiąg.

Także w okresie panowania Zygmunta Augusta nie wypracowano jedynego modelu kształtowania i kompletowania ksiąg sądowych władcy. Trwałość bądź zmiana tych zwyczajów zależały od różnych czynników. Ponieważ nie istniały żadne regulaminy pracy kancelarii, za wyjątkiem obowiązkowej przysięgi pisarza, a dokumenty procesu sądowego władcy i inne z nim związane sporządzali różni pisarze, w połowie XVI w. coraz częściej układali oni „swoje” księgi sądowe, a na

73 Cyt. za: A. Dubonis, D. Antanavičius, R. Ragauskienė, R. Šmigelskytė-Stukienè, op. cit., s. 82.

${ }^{74}$ ML 35, nr 49, s. 87-92; ML 37, nr 116, s. 138.

75 ML 37, nr 122, s. 148-149; ML 35, nr 51, s. 99.

${ }^{76}$ ML 37, nr 116, s. 138; ML 35, nr 51, s. 99. 
Irena Valikonytė

ich zakres chronologiczny wpływały również meandry kariery danego pisarza. Oczywiście tzw. pisarze wielcy (a do takiej kategorii zaliczał się też Jan Szymkowicz) mieli pomocników - diaków, którzy pracowali przy porządkowaniu dokumentów i zapewne przepisywali je do ksiąg. Jednak rozpoczęcie lub zakończenie konkretnej księgi zlecał pisarz, czasem „przykładając” też swą rękę̨7. Hipoteza o posiadaniu przez wielkich pisarzy „swoich kancelarii" ${ }^{78}$ jest jednak - moim zdaniem - nieuzasadniona. W każdym razie nie da się jej udowodnić w przypadku Jana Szymkowicza, który w ciągu całej swojej kariery pisarskiej w zasadzie nie zdołał utworzyć ani jednej księgi Metryki przeznaczonej do wieczystego przechowywania. A zakres chronologiczny większości ksiąg sądowych władcy zależał (z pewnymi wyjątkami) od terminów sesji sądowych, czasem zaburzanych z powodu ważnych spraw państwowych, a także zwoływania sejmów Wielkiego Księstwa i Korony. Nieistotnym czynnikiem były natomiast podróże władcy, gdyż zainteresowane strony procesowe często podążały w ślad za nim ${ }^{79}$. Nie widać również, przynajmniej wyraźnie, wpływu kanclerza, który daje się np. dostrzec w przypadku Olbrachta Gasztołda w tworzeniu 4. KSS ${ }^{80}$. Z pewnością nie było też dużego chaosu w działalności kancelarii Wielkiego Księstwa. Wreszcie specyfika pracy sądu i coraz większe znaczenie dokumentu i jego miejsce w stylu życiu szlachty wymagało od pisarzy sądowych wydawania oryginalnych dokumentów na czas. A ich odpisy mogły zaczekać.

\section{Streszczenie}

Zagadnienie genezy i tworzenia ksiąg Metryki Litewskiej według charakteru dokumentów było dotychczas rozpatrywane najczęściej poprzez badanie ksiąg najwcześniejszych (z okresu od końca XV do początku XVI w.), tzw. ksiąg wpisów. Analiza ksiąg sądowych władcy z tego okresu pokazała, że nie istniał wtedy jeszcze jednolity model układu ksiąg spraw sądowych, a chronologia wpisanych dokumentów zależała od takich czynników jak itinerarium władcy, działalność zawodowa pisarza spisującego dokumenty sądowe oraz poziom kultury piśmiennictwa. W niniejszym artykule badano układ sześciu ksiąg sądu władcy, w celu zbadania, czy model archiwizacji dokumentów tego sądu zmienił się w połowie XVI w. Ustalono, że dokumenty działalności sądu, któremu Zygmunt August przewodził w latach 1554-1568, spisano do pięciu ksiąg. Powtarza się w nich chronologia, ale nie zawartość. Jednak jedna z nich, tzw. 35. księga spraw sądowych, została utworzona z dokumentów obejmujących wyjątkowo długi okres - aż 14 lat. Okazało się też, że znajdująca się w Metryce Litewskiej 38. księga wpisów również zawiera dokumenty z tego samego okresu, ale innego rodzaju. W rejestrze oryginalnych ksiąg Metryki obie nazywane są księgami pisarza Jana Szymkowicza. Wypada zatem założyć, że pisarze królewscy segregowali dokumenty ze względu na ich charakter.

77 Oto w rejestrze oryginalnych ksiąg w nazwie księgi wskazano, że księga „ma tytuł pisany ręką jego mości pana Sawickiego"; D. Antanavičius, op. cit., s. 180, nr [148].

78 A. Dubonis, D. Antanavičius, R. Ragauskienė, R. Šmigelskytè-Stukienè, op. cit., s. 86.

79 Czasami także sam Zygmunt August nakazywał stronom procesowym znaleźć go tam, gdzie zatrzyma się z dworem, chociażby i za granicami Wielkiego Księstwa; zob. ML 35, nr 233, s. 295.

${ }^{80}$ Lietuvos Metrika (1522-1530). 4-oji teismu bylu knyga, wyd. S. Lazutka, I. Valikonyte, E. Gudavičius et al., Vilnius 1997, s. 41. 
Z drugiej strony oczywiste jest, że w kancelarii Wielkiego Księstwa Litewskiego nie istniał „specjalistyczny" pisarz sądowy, sprawy protokołował ten z nich, który znajdował się w owym czasie przy władcy i nie był zajęty wykonywaniem innych jego zleceń. Tym można wyjaśnić fakt, że niektóre z ksiąg sądowych mają „nakładającą się" chronologię, a dokumenty sporządzone w tym samym roku trafiały do różnych ksiąg sądowych. Na pytanie o tak długi zakres chronologiczny księgi Szymkowicza (nietypowy dla ksiąg z tego okresu) pozwala odpowiedzieć list Zygmunta Augusta pisany już po śmierci Szymkowicza (w 1569) do Mikołaja Radziwiłła „Rudego”. Wynika z niego, że pisarz ten większość odpisów dokumentów i skompletowanych z nich poszytów przechowywał w swoim domu. Dlatego można przypuszczać, że oryginalne księgi mogły zostać spisane już po jego śmierci z prowadzonych przez niego poszytów. Analiza struktury tej i innych ksiąg spraw sądowych (24., 34., 37. i 47.) pozwala stwierdzić, że w połowie XVI w. w kancelarii Wielkiego Księstwa Litewskiego nie został wprowadzony jednolity model tworzenia ksiąg sądowych władcy, jednak proces kompletowania takich ksiąg bezspornie znalazł się w rękach tzw. pisarzy wielkich, tzn. poszyty dokumentów spisanych przez konkretnego pisarza stawały się podstawą do utworzenia odrębnej księgi. Jednak ich struktura zależała także od innych czynników (np. od specyfiki działalności sądu władcy, od długości i periodyczności sesji sądowych, które czasem zaburzały ważne sprawy państwowe). A o charakterystycznym dla wszystkich ksiąg przestrzeganiu ciągłości chronologicznej we wpisywaniu dokumentów najprawdopodobniej zadecydowała konieczność usprawnienia procesu poszukiwań potrzebnych dokumentów.

\section{The Structure and Pattern of Formation of Court Books to the Lithuanian Metrica under King Sigismund Augustus Summary}

Hitherto, the development of the books of the Lithuanian Metrica, as well as their categorisation by the character of the documents, has been studied mainly by focusing on the earliest, so-called books of entries from the late fifteenth and early sixteenth centuries. The analysis of the king's court registers from the same period revealed that no uniform pattern in forming of court records existed at that time, and the chronology of documents included in the books depended on factors such as the king's itinerary or court scribe's occupational activities and his written culture. This article explores the structure of six record books of the king's court and tries to ascertain whether the pattern for preserving this court's documents changed in the mid-sixteenth century. The research has revealed that the documents of the court presided over by King Sigismund Augustus in 1554-1568 were written in five books which overlapped as regards the chronology of the documents but were distinct in their contents. However, one of these registers, the so-called Court Record Book no. 35, is distinct in its chronological scope, for it was formed out of documents from the whole period of fourteen years. It became clear that the Book of Entries no. 38 also contains documents, though different in character, from the same period of fourteen years (1554-1568). In the inventory of original books of the Lithuanian Metrica both these books are referred to as the books of the scribe Jan Szymkowicz. Thus, the king's scribes categorised the documents according to their character. On the other hand, it is clear that there were no "specialist" scribes in the chancery of the Grand Duchy of Lithuania, and the cases were recorded by officials accompanying the king. This explains the overlapping chronology of some of these books and why documents written in the same year ended up in different books. Sigismund Augustus' letter to Mikołaj Radziwiłł called Rudy (The Red) written after Szymkowicz's death (1569) sheds light on the question why the chronological scope of Szymkowicz's books was so unusually broad. The letter reveals that the scribe kept the duplicates of numerous documents and "notebooks" at home. Therefore, it could be supposed that the original books composed of the scribe's "notebooks" could have been assembled after his death. The analysis of the structure of these and other 
court registers (nos. 24, 34, 37, 40, and 47) shows that there was no uniform pattern to be followed in order to make the king's court registers in the chancery of the Grand Duchy of Lithuania in the mid-sixteenth century. It is clear, however, that grand scribes undertook the process of book formation: the "notebooks" containing the documents written by a scribe formed a basis for an individual court record book. Nonetheless, their internal structure depended on other factors as well (e.g. the activities of the king's court, the duration and periodicity of court sessions, which were often interrupted by important state affairs). The chronological consistency of the entries, common to all the books, was most likely determined by the practical demand to quicken the search of the requested documents.

\section{Bibliografia}

\section{Źródła publikowane}

Kojalavičius-Vijūkas A., Šventasis Lietuvos Didžiosios Kunigaikštijos bei jai priklausančiu provinciju giminiu ir herbu vardynas, wyd. i tłum. S. Narbutas, Vilnius 2015.

Lietuvos Didžiosios Kunigaikštystès ir Maskvos valstybès sutartys 1449-1556 metai, wyd. M. Sirutavičius, Vilnius 2016.

Lietuvos Metrika (1522-1530). 4-oji teismų bylų knyga, wyd. S. Lazutka, I. Valikonytė, E. Gudavičius et al., Vilnius 1997.

Lietuvos Metrika (1540-1541). 10-oji teismų bylu knyga, wyd. S. Lazutka, I. Valikonytè, S. Viskantaitè-Saviščevienè, Vilnius 2003.

Lietuvos Metrika (1554-1568). 35-oji teismu bylu knyga, wyd. S. Viskantaitè-Saviščevienè, I. Valikonyte, Vilnius 2018.

Lietuvos Metrika (1555-1558). 37-oji teismu bylu knyga, wyd. I. Valikonytė, L. Steponavičienè, Vilnius 2010.

Lietuvos Metrika (1559-1563). 40-oji teismu bylu knyga, wyd. N. Šlimienė, I. Valikonyte, Vilnius 2015.

Lietuvos Metrika (1562-1566). 47-oji teismu bylu knyga, wyd. I. Valikonytė, N. Šlimienè, Vilnius 2011.

Lietuvos Metrika (1565-1566). 50-oji teismu bylu knyga, wyd. L. Steponavičienė, I. Valikonytė, Vilnius 2014.

Lietuvos Metrika. Knyga nr. 29 (1546-1547). Užrašymų knyga 29, wyd. I. Ilarienė, Vilnius 2016.

Lietuvos Metrika. Knyga nr. 47 (1565-1567). Užrašymu knyga 47, wyd. E. Deveikytė, G. Lesmaitis, Vilnius 2018.

Lietuvos Metrika. Knyga nr. 51 (1566-1574). Užrašymų knyga 51, wyd. A. Baliulis, R. Ragauskienè, A. Ragauskas, Vilnius 2000.

Listy króla Zygmunta Augusta do Radziwiłłów, oprac., wstęp i koment. I. Kaniewska, Kraków 1999. Метрыка Вялікага Княства Літоўскага. Кніга 30 (1480-1546). Кніга записаў $N^{\circ}$ 30, wyd. В.С. Мянжынскі, Мінск 2008.

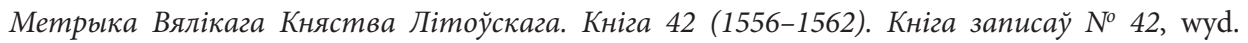
В.С. Мянжынскі, Мінск 2015.

\section{Opracowania}

Antanavičius D., Originaliu Lietuvos Metrikos XVI a. knygu sq̨ašas, „Istorijos šaltinių tyrimai” 4, 2012, s. 157-184.

Banionis E., Lietuvos Didžiosios Kunigaikštystés pasiuntinybiu tarnyba XV-XVI amžiais, Vilnius 1998. 
Banionis E., Lietuvos Metrikos knygos: sąvoka, terminas, definicija, „Lietuvos istorijos metraštis 1988 metai" 1989 , s. 135-148.

Cynarski S., Zygmunt August, Wrocław 1988.

Dubonis A., Antanavičius D., Ragauskienė R., Šmigelskytė-Stukienė R., Susigrąžinant praeitį. Lietuvos Metrikos istorija ir tyrimai, Vilnius 2016.

Karalius L., Lietuvos Metrikos knygu vaidmuo Aleksandro Jogailaičio kanceliarijoje (problemos aktualumas ir tyrimo perspektyvos), „Istorijos šaltinių tyrimai” 1, 2008, s. 175-217.

Kiaupienè J., XVI a. ikireforminio Vilniaus pilies teismo knygos-kopijos Lietuvos Metrikoje struktūrinè ir informacine analizè, w: Lietuvos Metrika. 1991-1996 metu tyrinèjimai, Vilnius 1998, s. 36-90.

Kolankowski L., Zygmunt August wielki książę Litwy do roku 1548, Lwów 1913.

Lazutka S., Valikonyte I., Sinkevičiūtė J., țadas, w: Lietuvos Metrika (1533-1535). 8-oji teismu bylu knyga, Vilnius 1999, s. XII-XIX.

Lulewicz H., Szymkowicz (Symkowicz) Jan, w: PSB, t. 50, Warszawa-Kraków 2015, s. 262-265.

Pietkiewicz K., Księga 9 wpisów (заnuceŭ) Metryki Litewskiej, układ i zawartość, oraz jej kontynuacja do roku 1518 z Archiwum Radziwiłłowskiego, w: Lietuvos Metrika. 1991-1996 metu tyrinëjimai, Vilnius 1998, s. 11-35.

Pietkiewicz K., Wielkie Księstwo Litewskie pod rządami Aleksandra Jagiellończyka. Studia nad dziejami państwa i społeczeństwa na przełomie XV i XVI wieku, Poznań 1995.

Ragauskienè R., XVI a. Lietuvos Didžiosios Kunigaikštystès kancleriai ir Lietuvos Metrika: valstybès kanceliarijos dokumentu saugojimo ypatybés, „Lietuvos Metrikos naujienos” 2003, nr 7, s. 30-40.

Ragauskienè R., Lietuvos Didžiosios Kunigaikštystès kancleris Mikalojus Radvila Rudasis (apie 1515-1584), Vilnius 2002.

Ragauskienė R., Mirties nugalèti nepavyko. Biržu ir Dubingių kunigaikščiu Radvilų biologine istorija (XV a. pabaiga - XVII a.), Vilnius 2017.

Szymański J., Nauki pomocnicze historii, wyd. 5, nowe, przejrz. i zm., Warszawa 2002.

Urzędnicy centralni i dostojnicy Wielkiego Księstwa Litewskiego XIV-XVIII wieku. Spisy, oprac. H. Lulewicz, A. Rachuba, Kórnik 1994.

Valikonytė I., W poszukiwaniu modelu układu najstarszych ksiag spraw sądowych Metryki Litewskiej, w: Lietuvos Didžiosios Kunigaikštystès istorijos šaltiniai: faktas, kontekstas, interpretacija, red. A. Dubonis, Vilnius 2010, s. 109-127.

Банёнис Э., К вопросу о генезисе посольских книг (1480-1486), w: Исследования по Литовской Метрике, t. 1, Москва 1989, s. 64-84.

Банионис Э., К вопросу о генезисе книг Литовской Метрики (последняя четверть XV в.), w: Lietuvos Metrika: 1988 metu tyrinejimai, Vilnius 1992, s. 8-45.

Бережков Н., Литовская Метрика как исторический источник, t. 1: О первоначальном составе книг Литовской Метрики по 1522 год, Москва-Ленинград 1946.

Голенченко Г., Реестр книг Метрики Великого княжества Литовского 1623 г. Исследования по истории Литовской Метрики, t. 2, Москва 1989, s. 336-356.

Груша А., Канцылярыя Вялікага княства Літоўскага 40-х гадоў XV - першай паловы XVI cm., Мінск 2006.

Лаппо И.И, Великое княжество Литовское за время от заключения Люблинской унии до смерти Стебана Батория (1569-1586), С. Петербург 1901.

Любавский М., Литовско-Русский сейм, Москва 1900.

Пташицкий С., Описание книг и актов Литовской Метрики, Санкт Петербург 1887.

Irena Valikonytė - dr, profesor Wydziału Historycznego Uniwersytetu Wileńskiego. Zainteresowania badawcze: historia prawa Wielkiego Księstwa Litewskiego, Statut Litewski, Metryka Litewska, status prawny kobiet w Wielkim Księstwie Litewskim. E-mail: irena.valikonyte@if.vu.lt 